\title{
3.2.9. Remediation of soil contaminated with persistent organic pollutants in Sumgait, Azerbaijan
}

\author{
Petr Sharov', Rovshan Abbasov², Alena Temnikova 3
}

${ }^{1}$ Blacksmith Institute Pure Earth, petr@pureearth.org

${ }^{2}$ Khazar University, abbasov@hotmail.com

3Far Eastern Federal University, Blacksmith Institute Pure Earth

\begin{abstract}
The Sumgait remediation project was implemented in 2015 as a partnership between Blacksmith Institute and the site owner Azerikimya Joint Stock Company (Azerikimya) in Sumgait City, Azerbaijan Republic, about $30 \mathrm{~km}$ northwest of Baku. The project was financed by European Commission and supported by the Ministry of Ecology and Natural Resources (MENR) and Sumgait Municipality. The site is a place on the Caspian Sea coast that was formerly an industrial area highly contaminated with various pollutants and particularly benzo(a)pyrene, benzene, and polychlorinated biphenyls (PCBs). As part of initial environmental assessment the project team took soil samples at 19 locations at the surface and at the depth of $0.5 \mathrm{~m}$. The maximum topsoil benzo(a)pyrene concentration was $76.21 \mathrm{mg} / \mathrm{kg}$, benzene $-121.5 \mathrm{mg} / \mathrm{kg}$, and PCBs - 121.02 $\mathrm{mg} / \mathrm{kg}$. The remediation project involved the removal of $804 \mathrm{~m}^{3}$ of contaminated soil, and disposal of the contaminated soil at the MENR Hazardous Waste Polyqon (landfill). A comparison of pre- and post-excavation sampling shows that average contaminant levels in soils in the upper $0.5 \mathrm{~m}$ were reduced by an average of 97 percent. These actions were followed by bioremediation activities. More than 13,000 $\mathrm{m}^{3}$ of clean soil and organic fertilizer were placed and leveled over an area of two hectares. Approximately 1,200 locally grown native tree species were planted, and a drip-irrigation system was installed. The area is now a park close to the beach.
\end{abstract}

Keywords: remediation, chemical contamination, Sumgait, Azerbaijan

\section{Introduction, scope and main objectives}

Sumgait is the third largest city of Azerbaijan with a population over 300,000 people. During the Soviet era, Sumgait was a major industrial center with more than 40 factories that produced various metals and chemicals. Over the last decade, the municipal, national government, and local industries have taken important steps to reduce the impacts of the city's industrial legacy, including closing polluting factories, upgrading facilities, treating contaminated wastewater and transferring contaminated materials to a secure facility (Eminov 2012). Despite this progress, regional soil test results show that large areas are still highly contaminated with heavy metals and other pollutants known to impact human health. If old obsolete industrial facilities are removed and pollution cleaned up that would allow using the land for other purposes, for instance creating new park areas for recreation (Ismailov 2009, Mamedov 2011, Kahramanova 2012).

For the pilot soil cleanup project a highly contaminated area was selected in Sumgait. The site is a small piece of the larger Sumgait industrial area, northwest of the main part of the city. The area is dry and the vegetation is sparse, with sandy soil. The closest residential areas are about $1.5 \mathrm{~km}$ away. The site was a high priority for remediation because it is located on the Caspian Sea, where the public used this highly contaminated area as a beach.

The site used to be a disposal area for wastewater residue from the state-owned Organic Synthesis Plant and Ethylene-Propylene Plant. Organic wastes containing benzene, benzo(a)pyrene, and 
polychlorinated biphenyls (PCBs) originated primarily from the former Organic Synthesis Plant and the Ethylene-Propylene Plant. Wastewater discharge from the Ethylene Propylene Plant was completely stopped before remediation began, and the Organic Synthesis Plant was decommissioned in recent years. The closed Organic Synthesis Plant used to produce propylene oxide, propylene glycol, and polyester resins.

The site was used to settle and evaporate liquid chemical wastes from the Organic Synthesis Plant and as a wastewater pumping station for the plant. The liquid waste entered the site through a pipe. There was a settling/evaporation pond, and some of the waste was pumped from the pond to another site for treatment. After settling and evaporation, the sludge was periodically cleaned out of the pond and placed on the ground. The pond sometimes overflowed, and wastes spread to the north and south.

The goal of the project was to eliminate health risks to people from the site.

The project objectives included:

1. Environmental assessment to determine the levels and extent of contamination;

2. Soil cleanup;

3. Post-cleanup assessment of soil residual contamination;

4. Revegetation of the area.

The project was implemented by the Blacksmith Institute/Pure Earth and Azerikimya Company, supported by Sumgait Municipality, Ministry of Ecology and Natural Resources (MENR) of Azerbaijan, and co-financed by European Commission.

\section{Methodology}

The environmental assessment of the area was conducted in order to determine the concentrations of main contaminants: benzene, polychlorinated biphenyls (PCBs), and benzo(a)pyrene. The site was mapped and targeted soil samples were collected. Soils samples were taken near the settling pond as the assumed main source of contamination, along the perimeter of contaminated area and between the settling pond and borders of the site. Geographic coordinates of all samples were recorded. At each location samples were collected at the surface and at the depth of $0.5 \mathrm{~m}$. Soil samples were analyzed in Environmental Laboratory of State Oil Company of Azerbaijan Republic (SOCAR).

The results were mapped using ArcGIS 10.2. The spatial data was organized in shapefiles. Background georeferenced images for mapping were obtained through SAS.Planet software.

The main cleanup method was to remove the most contaminated soil and place it to the special Hazardous Waste Storage (Polyqon) of MENR. The removal was conducted using heavy machinery: excavator and trucks. Transportation of contaminated soil followed safety regulations of Azerbaijan. The results of the soil contamination assessment were used to determine where the most contaminated soil is located at the site. After the contamination was removed new clean fertile soil was brought in for the purposes of revegetation and also to exclude contact of people with remaining contaminants. 


\section{Results}

In July 2015 the project team collected samples at 19 locations. The maximum concentration of benzo(a)pyrene in topsoil was $76.21 \mathrm{mg} / \mathrm{kg}$, at the depth of $0.5 \mathrm{~m}-51,45 \mathrm{mg} / \mathrm{kg}$, the lowest concentration was below level of detection (LoD). The maximum concentrations of benzo(a)pyrene exceeded United States Environmental Protection Agency (USEPA) standard of $2.1 \mathrm{mg} / \mathrm{kg}$ for industrial soils more than 38 times. The maximum concentration of PCBs in topsoil was 121.02 $\mathrm{mg} / \mathrm{kg}$, minimum $-0.15 \mathrm{mg} / \mathrm{kg}$. At the depth of $0.5 \mathrm{~m}$ the maximum concentration of PCBs -73.29 $\mathrm{mg} / \mathrm{kg}$, minimum - below LoD. The maximum concentration of PCBs at the site exceeded USEPA standard of $0.94 \mathrm{mg} / \mathrm{kg}$ for industrial soils more than 120 times. The maximum concentration of benzene in was $109.5 \mathrm{mg} / \mathrm{kg}$, minimum $-0.73 \mathrm{mg} / \mathrm{kg}$. The maximum concentration of benzene in soil at the depth of $0.5 \mathrm{M}$ was $121.5 \mathrm{mg} / \mathrm{kg}$, minimum - below LoD. The maximum concentration of PCBs at the site exceeded USEPA standard of $5.1 \mathrm{mg} / \mathrm{kg}$ for industrial soils more than 24 times. Most concentrations of contaminants at the site exceed both industrial and residential USEPA standards for soil. This is a former industrial area, but now it is a public area, so the residential soil standards should apply. The concentrations tend to be lower at the depth of $0.5 \mathrm{~m}$. The results are presented in Table 1.

Table 1. Concentrations of benz[a]pyrene, PCB, and benzene in soil before remediation

\begin{tabular}{|c|c|c|c|c|c|c|}
\hline \multirow{3}{*}{ № } & \multicolumn{6}{|c|}{ Concentrations, mg/kg } \\
\hline & \multicolumn{2}{|c|}{ Benzo(a)pyrene } & \multicolumn{2}{|c|}{ PCB } & \multicolumn{2}{|c|}{ Benzene } \\
\hline & Surface & $\underset{\text { m }}{\underset{\text { Depth }}{0.5}}$ & Surface & $\begin{array}{l}\text { Depth } \\
\text { m }\end{array}$ & Surface & $\underset{\text { mepth }}{0.5}$ \\
\hline 1 & 0.033 & 0.000 & 0.65 & 0.21 & 1.21 & 0.92 \\
\hline 2 & 0.087 & 0.119 & 2.44 & 1.17 & 1.78 & 0.35 \\
\hline 3 & 76.210 & 51.450 & 33.08 & 12.89 & 4.32 & 2.65 \\
\hline 4 & 32.930 & 21.310 & 64.02 & 21.32 & 1.95 & 0.45 \\
\hline 5 & 0.008 & 0.000 & 2.87 & 1.91 & 1.11 & 0.98 \\
\hline 6 & 0.009 & 0.005 & 1.28 & 1.31 & 0.83 & 1.03 \\
\hline 7 & 0.000 & 0.000 & 0.15 & 0.06 & 1.14 & 0.65 \\
\hline 8 & 5.120 & 3.920 & 2.21 & 3.29 & 0.73 & 3.87 \\
\hline 9 & 12.430 & 3.110 & 42.91 & 31.41 & 2.11 & 2.82 \\
\hline 10 & 28.900 & 11.620 & 121.02 & 73.29 & 8.41 & 2.22 \\
\hline 11 & 64.200 & 23.090 & 84.32 & $45 \cdot 39$ & 6.81 & 2.89 \\
\hline 12 & 0.060 & 0.000 & 1.09 & 0.76 & 1.04 & 0.55 \\
\hline 13 & 3.310 & 1.760 & 34.30 & 6.11 & 4.43 & 4.01 \\
\hline 14 & 0.005 & 0.000 & 0.63 & 0.67 & 1.01 & 0.43 \\
\hline 15 & 11.900 & 12.100 & 1.34 & 2.56 & 109.50 & 92.10 \\
\hline 16 & 9.600 & 8.400 & 1.21 & 0.98 & 88.40 & 121.50 \\
\hline 17 & 21.900 & 11.900 & 2.43 & 3.71 & 66.10 & 72.30 \\
\hline 18 & 19.200 & 6.100 & 3.19 & 1.23 & 23.30 & 56.40 \\
\hline 19 & 12.500 & 0.000 & 7.10 & $\mathrm{O}$ & 64.10 & $\mathrm{O}$ \\
\hline Mean & 15.7 & 8.2 & 21.4 & 11.0 & 20.4 & 19.3 \\
\hline $\begin{array}{lc}\text { Rec level } & \text { for } \\
\text { residential soils } & \end{array}$ & & 0.11 & & 0.23 & & 1.2 \\
\hline $\begin{array}{lc}\text { Rec level } & \text { for } \\
\text { industrial soils } & \end{array}$ & & 2.1 & & 0.94 & & 5.1 \\
\hline
\end{tabular}


The next stage of the project was removal of $804 \mathrm{~m}^{3}$ of contaminated soil, and disposal of the contaminated soil at the MENR Hazardous Waste Storage (Polyqon). This was done in February 2016. The volume and location of contaminated soil was determined by the previous soil sampling and mapping. After the removal of contaminated soil the area was sampled again to determine the levels of remaining contamination at the site.

The maximum concentration of benzo(a)pyrene in topsoil was $0.41 \mathrm{mg} / \mathrm{kg}$, at the depth of $0.5 \mathrm{M}-$ $1,56 \mathrm{mg} / \mathrm{kg}$. The maximum concentration of PSBs in topsoil was $0.98 \mathrm{mg} / \mathrm{kg}$, at the depth of $0.5 \mathrm{M}$ $-1.07 \mathrm{mg} / \mathrm{kg}$. The maximum concentration of benzene in topsoil was $0.02 \mathrm{mg} / \mathrm{kg}$, at the depth of $0.5 \mathrm{M}-0.07 \mathrm{mg} / \mathrm{kg}$. The minimum concentrations of contaminants were below LoD. The results are presented in Table 2.

Table 2. Concentrations of benz[a]pyrene, $\mathrm{PCB}$, and benzene in soil after remediation

\begin{tabular}{|c|c|c|c|c|c|c|}
\hline \multirow{3}{*}{ № } & \multicolumn{6}{|c|}{ Concentrations, mg/kg } \\
\hline & \multicolumn{2}{|c|}{ Benzo(a)pyrene } & \multicolumn{2}{|l|}{ PCB } & \multicolumn{2}{|l|}{ Benzene } \\
\hline & Surface & $\begin{array}{l}\text { Depth } 0.5 \\
\text { m }\end{array}$ & Surface & $\begin{array}{l}\text { Depth } \\
\text { m }\end{array}$ & Surface & Depth 0.5 m \\
\hline 1 & 0.00 & 1.29 & 0.29 & 1.01 & 0.00 & 0.01 \\
\hline 2 & 0.23 & 1.01 & 0.00 & 0.31 & 0.02 & 0.02 \\
\hline 3 & 0.00 & 0.75 & 0.04 & 0.33 & 0.00 & 0.04 \\
\hline 4 & 0.00 & 0.44 & 0.00 & 1.07 & 0.00 & 0.00 \\
\hline 5 & 0.00 & 1.15 & 0.98 & 1.01 & 0.00 & 0.00 \\
\hline 6 & 0.04 & 0.91 & 0.45 & 1.03 & 0.00 & 0.00 \\
\hline 7 & 0.09 & 1.19 & 0.06 & 0.14 & 0.02 & 0.07 \\
\hline 8 & 0.41 & 1.56 & 0.00 & 0.71 & 0.00 & 0.01 \\
\hline 9 & 0.02 & 1.54 & 0.00 & 0.94 & 0.00 & 0.00 \\
\hline 10 & 0.00 & 0.02 & 0.00 & 0.02 & 0.00 & 0.01 \\
\hline 11 & 0.00 & 0.00 & 0.00 & 0.76 & 0.00 & 0.00 \\
\hline 12 & 0.00 & 0.01 & 0.00 & 0.91 & 0.00 & 0.00 \\
\hline Mean & 0.07 & 0.82 & 0.15 & 0.69 & 0.00 & 0.01 \\
\hline $\begin{array}{lc}\text { Rec level } & \text { for } \\
\text { residential soils } & \end{array}$ & & 0.11 & & 0.23 & & 1.2 \\
\hline $\begin{array}{lcc}\text { Rec level } & \text { for } \\
\text { industrial soils } & \end{array}$ & & 2.1 & & 0.94 & & 5.1 \\
\hline
\end{tabular}

Figures 1-3 show comparisons of concentrations of main contaminants before and after remediation and soil standards of USEPA. 


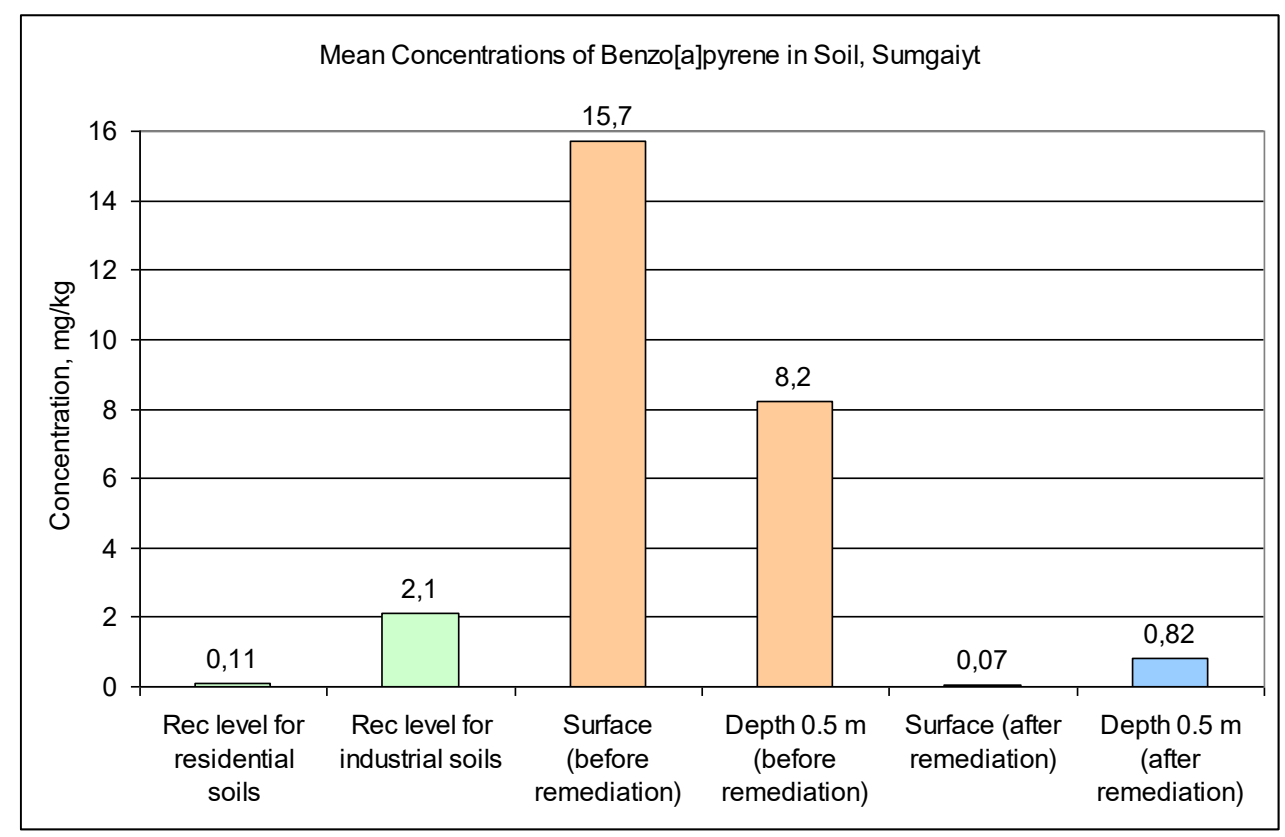

Figure 1. Mean concentrations of benzo[a]pyrene in topsoil and on the depth of $0.5 \mathrm{~m}$ before and after remediation

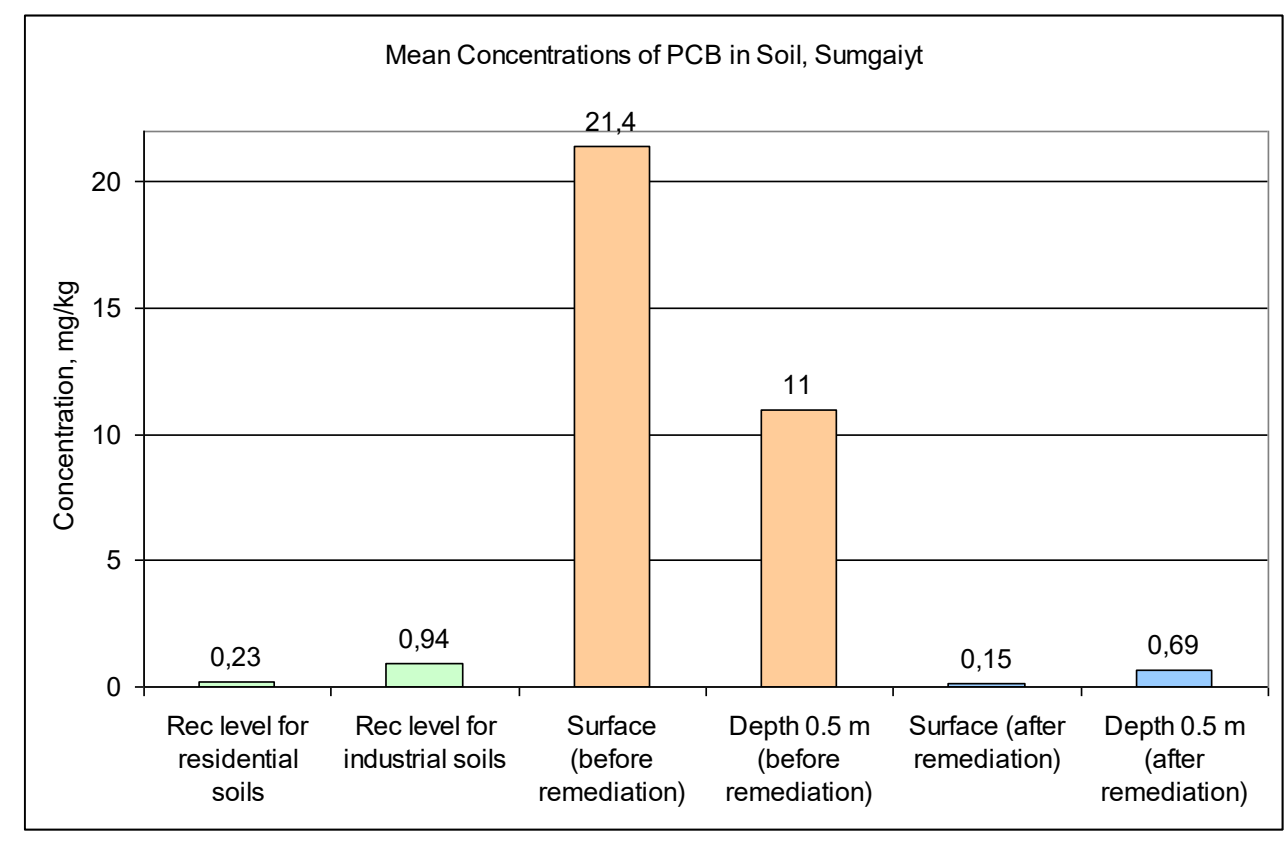

Figure 2. Mean concentrations of PCB in topsoil and on the depth of $0.5 \mathrm{~m}$ before and after remediation 


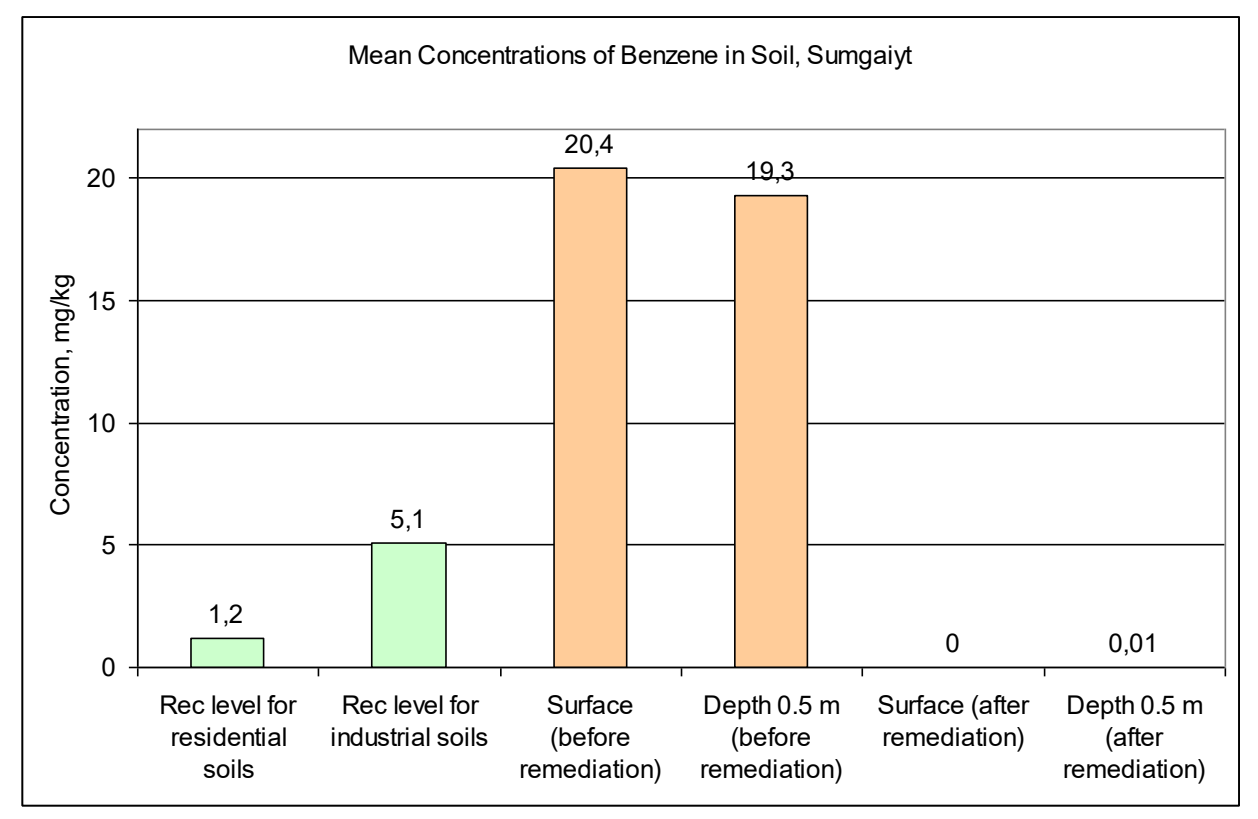

Figure 3. Mean concentrations of benzene in topsoil and on the depth of $0.5 \mathrm{~m}$ before and after remediation

Figures 4-6 show sampling locations and results of analyses for topsoil. These maps were used for planning removal of contaminated soil.
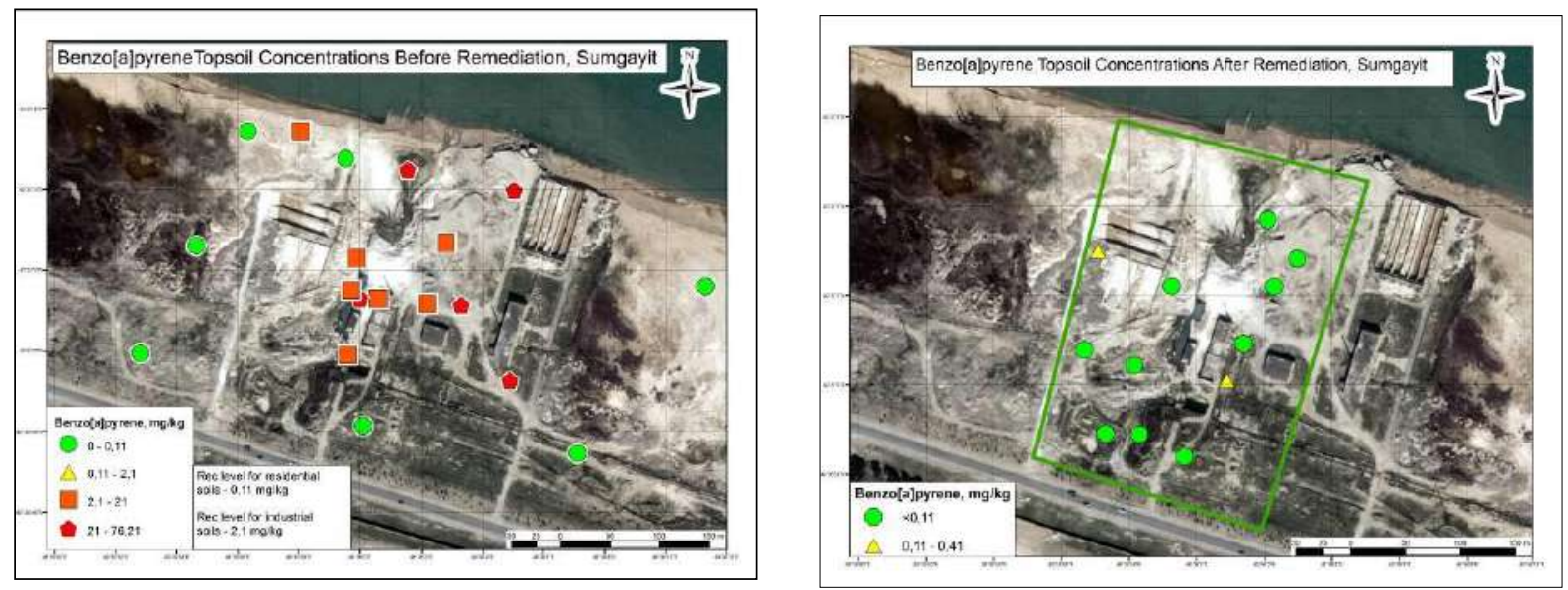

Figure 4. Concentrations of benzo[a]pyrene in topsoil before and after remediation 

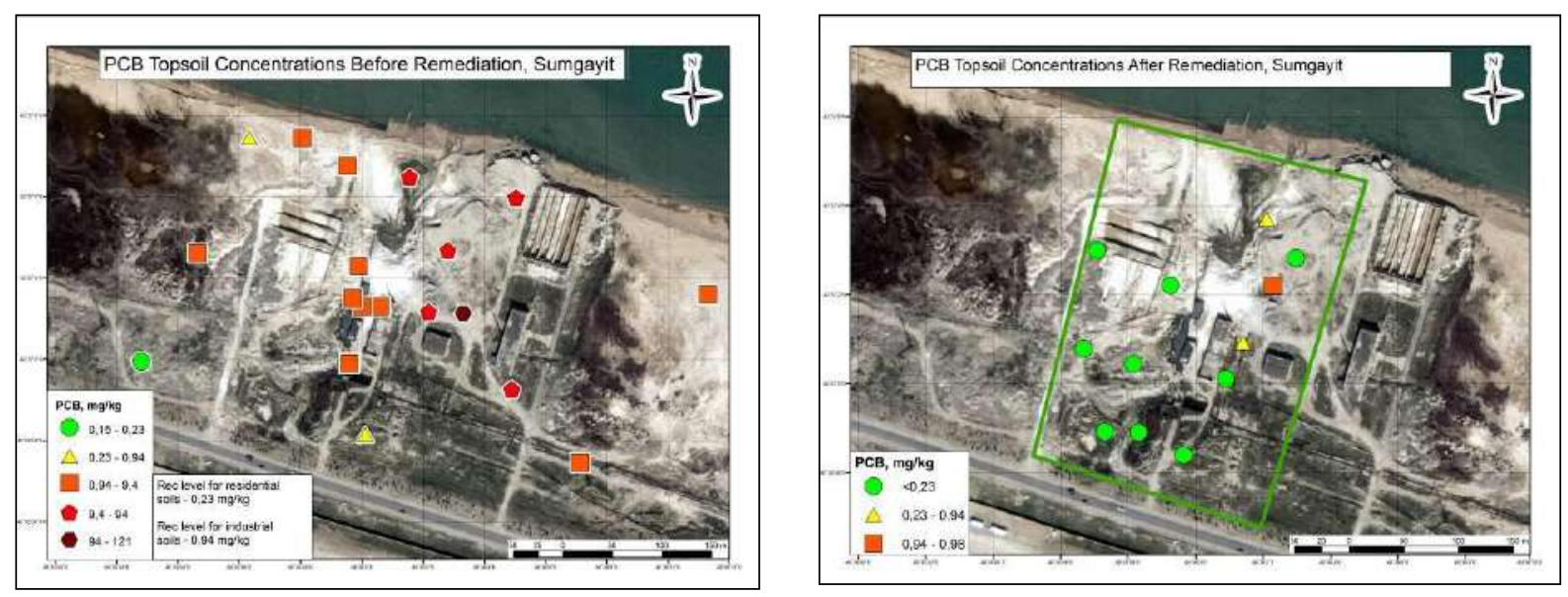

Figure 5. Concentrations of PCB in topsoil before and after remediation
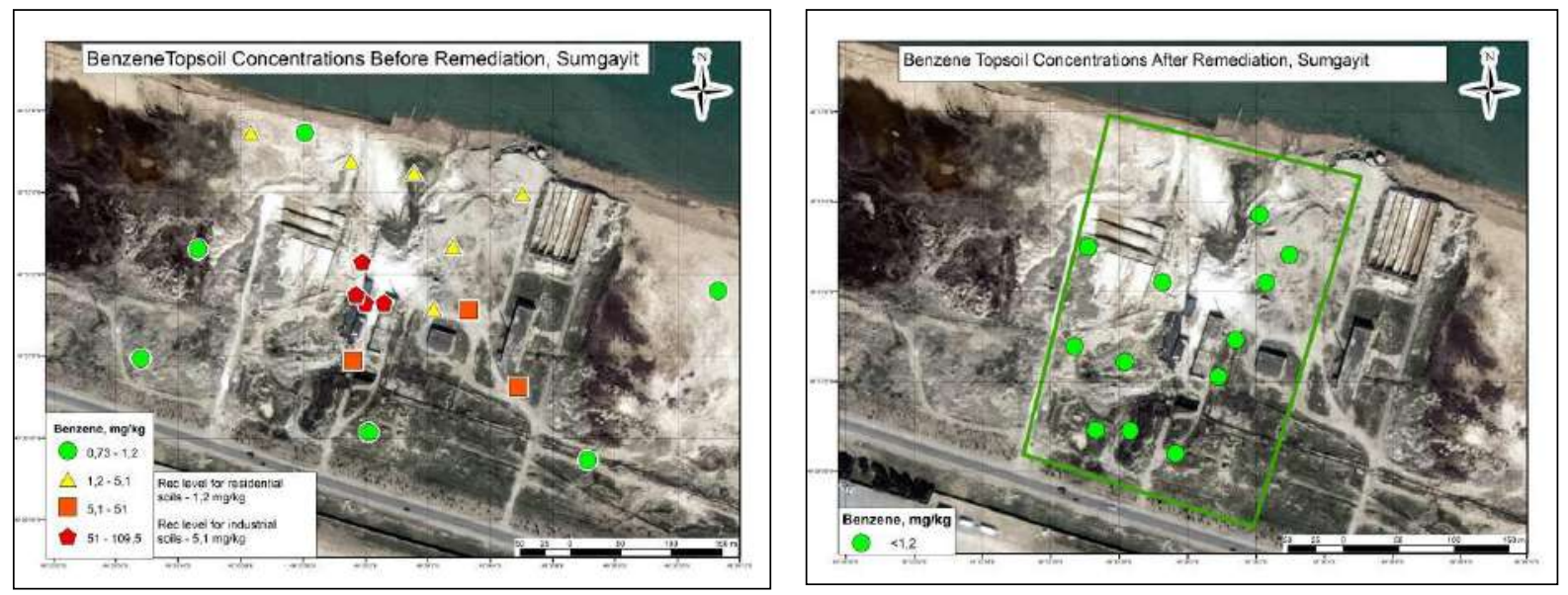

Figure 6. Concentrations of benzene in topsoil before and after remediation

At the next stage of the project in spring 2016 the area was graded and over 13,000 $\mathrm{m}^{3}$ of clean soil and $125 \mathrm{~m}^{3}$ of organic fertilizers were brought in. In June 2016 a drip irrigation system was installed and trees were planted. The revegetation plan was developed by Azerkimya and coordinated with Sumgait Municipality. Azerkimya used its nursery to provide seedlings. Over 2 hectares were revegetated with 1200 trees and bushes native to Absheron Peninsula: Olive (Olea europaea), Willow (Salix), Caspian Elaeagnus (Eleaegnus caspica), Eldar Pine or Pinus brutia (Pinus eldarica), Oriental Plane (Platanus Orientalis), Poplar (Populus), Flowering ash (Fraxinus ornus), White acacia (Robinia pseudoacacia). The drip-irrigation system is employed to help the trees to grow in their first years. It is anticipated that in several years the plants would survive without additional watering. The growth of trees is expected to contribute to further degradation of remaining contaminants at the site.

\section{Discussion}

The choice of methods for soil remediation in a contaminated area depends mainly on the type of contaminant, its concentrations and feasibility. The main methods include: chemically treating soil to degrade the contaminants or make them less bioavailable, capping the contamination with a layer of clean soil to prevent contact of people with toxic agents, using bioremediation, or removing contaminated materials. 
Chemical treatment of soil is often an expensive and labor intensive process because you would need to buy chemicals and mix it in large volumes of soil. And the list of contaminants that could be dealt with this way is limited. Therefore this option was not considered for the site in Sumgait.

Some organic contaminants may be degraded by plants and bacteria. Such methods work best when it is necessary to preserve the soil, the contamination levels are relatively low and there is enough time for the process. Bioremediation usually takes long time. Depending on the contamination levels and type of contaminants may take several years. In Sumgait there was no need to preserve original soil because it was mostly infertile sand. Also the concentrations of contaminants were very high and it was important to make the place for people safe fast. Therefore the bioremediation was not chosen as the primary method of clean up.

Capping the contaminated area with a layer of clean soil is usually used when the volume of contaminated materials is too big and contamination goes deep so it becomes impractical to extract it. The main disadvantage of capping is the necessity to maintain the barrier of clean soil for as long as the underlying contaminants remain toxic. In Sumgait the volume of contaminated soil was calculated and it was determined feasible to remove the most contaminated soil.

Mechanical removal of contaminated soil is most practical when the contamination levels are very high and there is a hazardous waste storage facility available (Rogozina and Morgunov 2016). This was the case in Sumgait. Therefore after careful consideration it was decided to dig out and remove most contaminated soil. Then the less contaminated soil was capped with a layer of clean soil. Then vegetation cover was established to prevent erosion of the layer of clean soil and contribute to biological remediation of the less contaminated soil beneath. So Sumgait project is an example of three methods combined.

The remaining contamination levels were measured before capping. The levels were much lower compared to those before remediation. But still some contamination remained. Further research would be necessary to study the effect of plants on degradation of the remaining contaminants.

\section{Conclusions}

The project was successful in turning the highly hazardous former industrial area into a small park absolutely safe for recreational activities. The project included standard stages: environmental assessment, selection of remediation methods, cleanup, post-cleanup environmental assessment, revegetation and making the area suitable for intended use. Soil sampling conducted by the project team indicated that before remediation the site was highly contaminated with such persistent toxic organic pollutants as benzo(a)pyrene, benzene, and PCBs. After the remediation the contamination levels dropped and the possibility of human contact with contamination excluded. The goal of the project achieved. The project also makes an example of productive cooperation of international nongovernmental organization, commercial company, and government agencies.

\section{Acknowledgements}

The authors thank Azerkimya and SOCAR for their dedication, hard work and financial contribution to the implemented project. Also the project team thanks the Ministry of Ecology and Natural Resources of Azerbaijan and Hazardous Waste Polyqon for substantial in-kind contribution and effective work. Special thanks go to UNIDO and European Commission for organizational and financial support that made the project possible.

The views expressed in this information product are those of the author(s) and do not necessarily reflect the views or policies of FAO. 


\title{
References
}

Eminov, Z.N. 2012. Changes in industrial structure of industry in large cities and regional centers of Azerbaijan. Scientific herald of Poltava University of Economics and Trade, 4(55): 4451.

EPA. 2017. Regional Screening Levels (RSLs) - Generic Tables (November 2017). Available at: https://www.epa.gov/risk/regional-screening-levels-rsls-generic-tables-november-2017 [accessed 13.02.18]

Ismailov, C.H.N. 2009. The main geological issues of Caspian. Bulletin of Dagestan State Pedagogical University, 4: 92-96.

Kahramanova, S.H. 2012. Anthropogenic pollution of soils in Absheron Peninsula. Akademicheskij vestnik UralNIIproekt RAASN, 1: 25-30.

Mamedov, B.A. 2011. The Current Situation and Development Prospects of the Economy of Sumgait City. Science Prospects, 3 (18): 133-137.

Rogozina, E.A. \& Morgunov, P.A. 2016. Method of a detailed preliminary examination of oilcontaminated soil and processing of received data for the rational choice of effective cleaning technology. Petroleum Geology - Theoretical and Applied Studies, 11(4). Available at: http://www.ngtp.ru/rub/7/48 2016.pdf [accessed 13.02.18]

\subsubsection{Initial approach for phytoremediation of petroleum hydrocarbons-mixed soil at oil industry in Skopje region}

\author{
Manasievska-Simikj Silvana, Mitkova Tatjana, Markoski Mile', Vasin Jovica3, \\ Stamatoska Angelina ${ }^{1}$, Georgievska Milijana², RikaloskaTatjana², Rikaloski Ice ${ }^{2}$
}

${ }^{1}$ Faculty of Agricultural Sciences and Food, 1000, Skopje, Republic of Macedonia. silvanam@fznh.ukim.edu.mk; smanasievska28@yahoo.com

${ }^{2}$ OKTA AD-Skopje, Republic of Macedonia

3Institute of Field and Vegetables Crops, Novi Sad, Serbia

\begin{abstract}
Phytoremediation has long been applied as a treatment technology that is cost-effective, ecologically friendly and efficient for the decontamination of hydrocarbon pollution (Saadawi et al. 2015). Rye (Secale cereale L.), barley (Hordeum vulgare L.) and wheat (Triticum aestivum L.) were selected in order to identify plants that can enhance the remediation of soil mixed with petroleum hydrocarbons. Field trials were established at oil refinery near Skopje, in randomized block system with three replications, in eighteen trial microplots. Soil was mixed with petroleum hydrocarbons in concrete basins with three layers providing high hydrophobic protection Laboratory experiment was designed in four variants with two replications (control, 3\% of soil/oil sludge, $5 \%$ of soil/ oil sludge, soil from the prepared basin). Laboratory analysis were performed to identify petroleum hydrocarbons content, some chemical and physical properties. The effect of the plant growth of on the hydrocarbons content and chemical properties of soil
\end{abstract}

